\title{
Chemical Composition and Antibacterial Activity of the Essential Oils Extracted From 4 Medicinal Plants (Labiatae) of Kerman, Iran
}

\author{
Ashraf Kariminik ${ }^{*}$, Mehran Moradalizadeh², Mohammad Mehdi Foroughi ${ }^{2}$, Hamid Tebyanian ${ }^{3}$, Mohammad Mehdi \\ Motaghi ${ }^{1}$
}

'Department of Microbiology, Kerman Branch, Islamic Azad University, Kerman, Iran

${ }^{2}$ Department of Chemistry, Kerman Branch, Islamic Azad University, Kerman, Iran

${ }^{3}$ Research Center for Prevention of Oral and Dental Diseases, Baqiyatallah University of Medical Sciences, Tehran, Iran

Corresponding Author: Ashraf Kariminik, PhD, Assistant Professor, Department of Microbiology, Kerman Branch, Islamic Azad University, Kerman, Iran. Tel: +98-9133413556, Email: a.kariminik@iauk.ac.ir

Received March 16, 2019; Accepted August 11, 2019; Online Published December 5, 2019

\begin{abstract}
Introduction: In many parts of the world, a rich tradition of using herbal medicine have been formed through history for treating many infectious diseases. Because of the side effects and the resistance that pathogenic microorganisms build against the antibiotics, much recent attention has been paid to extract biologically active compounds from plant species used in herbal medicine. The aim of this study was to determine the antibacterial activity of four medicinal plants' essential oils from Labiatae family - Salvia macrosiphon, Rosmarinus officinalis, Dracocephalum polychaetum, and Origanum vulgare - on four pathogenic bacteria as well as identify their chemically active compound.

Materials and Methods: The essential oil was extracted using hydro-distillation method. Then, analyzed by gas chromatography (GC) and gas chromatography-mass spectrometry (GC/MS) and compounds were identified. The antibacterial activity of the oil was evaluated using agar disc diffusion method. Minimum inhibitory concentration (MIC) and Minimum Bactericidal Concentration (MBC) were determined in a broth dilution assay.

Results: Most of the evaluated bacteria species were sensitive to the oils. MICs and MBCs showed that these 4 plants relatively had high efficacy against bacteria. More than $90 \%$ of the chemical contents of the oils was determined.

Conclusions: The obtained results suggest and justify using the indigenous plants' essential oils in traditional medicine as a treatment for microbial infections or as a preservative in food.

Keywords: Antibacterial Activity, Chemical Constituents, Labiatae, Essential Oil

Citation: Kariminik A, Moradalizadeh M, Foroughi MM, Tebyanian H, Motaghi MM. Chemical composition and antibacterial activity of the essential oils extracted from 4 medicinal plants (Labiatae) of Kerman, Iran. J Appl Biotechnol Rep. 2019;6(4):172-179. doi:10.29252/JABR.06.04.07.
\end{abstract}

\section{Introduction}

The increasingly growing rate of bacteria resistance to the antibiotics requires developing and searching for new antimicrobial agents. ${ }^{1}$ Compounds derived from the medicinal plants have gained widespread interest in respect to the search of alternative antibacterial agents. The reason is this perception exists that they are safe and have a long history of being used in folk medicine for treating infectious diseases. ${ }^{2,3}$ Natural products of higher plants may possess a new source of antibacterial agents with possibly novel mechanisms of action. Organized and methodical screening of them may result in discovering novel active compounds. ${ }^{4}$ Essential oils of the aromatic plants are compounds with different therapeutic characteristics, including antimicrobial effects. ${ }^{5}$ Besides, essential oils have also shown to exert antiviral, ${ }^{6}$ antimycotic, ${ }^{7}$ antitoxigenic, ${ }^{8}$ antiparasitic, ${ }^{9}$ and insecticidal activities, ${ }^{10}$ which are attributed to the function of their special compounds.
As it mentioned, the increasing microbial resistance against antibiotics has naturally led to search for new antimicrobial agents. ${ }^{1}$ Labiatae or Lamiaceae, also called as the mint family, is a family of flowering plants. The enlarged Labiatae contains about 236 genera and 6900-7200 species. The largest genera are respectively Salvia (900), Scutellaria (360), Stachys (300), Plectranthus (300), Hyptis (280), Teucrium (250), Vitex (250), Thymus (220) and Nepeta (200). ${ }^{11}$ In Iran, the Lamiaceae family is represented by 46 genera and 410 species/subspecies, of which 74 species have been mentioned as the medicinal plant in ancient Iranian medicinal literature. ${ }^{12}$ It is well recognized that some plants belonging to the Labiatae family possess suitable medicinal properties which are generally attributed to the presence of essential oils. ${ }^{13}$ Salvia genus includes around 58 species in Iran. ${ }^{14}$ Namely, Salvia macrosiphon is native to Iran, Iraq, Pakistan, Afghanistan, Transcaucasia, and Turkey. ${ }^{15}$ Rosmarinus officinalis is thought to be originated in the Mediterranean region as a wild, strewing evergreen

Copyright (C) 2019 The Author(s). This is an open-access article distributed under the terms of the Creative Commons Attribution License (http:// creativecommons.org/licenses/by/4.0), which permits unrestricted use, distribution, and reproduction in any medium, provided the original work is properly cited. 
perennial shrub. ${ }^{16,17}$ R. officinalis has been hailed since ancient times for its medicinal properties. Rosemary is used topically for preventing and treating baldness, toothache, eczema, muscle pains such as myalgia, intercostal neuralgia, cough, headache, high blood pressure, loss of appetite, in-bath therapy (balneotherapy), as well as for reducing age-related memory loss and wound healing. ${ }^{18,19}$ Dracocephalum is a genus of about 60 to 70 species of flowering plants in Labiatae family. ${ }^{20,21}$ Dracocephalum polychaetum is found abundantly in southwestern Asia, including Iran which is one of the indigenous species of Dracocephalum genus. ${ }^{22} \mathrm{D}$. polychaetum has been used as a herbal medicine for several years due to its therapeutic properties such as antihyperlipidemic and immunomodulatory effects, and as a flavoring in foods. ${ }^{22,23}$ Origanum vulgare is a common species of Origanum, a genus from Labiatae. ${ }^{24}$ Totally, 38 Origanum species are documented in the world. O. vulgare L. is the only species of the Origanum genus growing wild in Iran. It can grow to 80 $\mathrm{cm}$ in height. Leaves are dark green, oval, and opposite. $O$. vulgare has been used as a culinary and medicinal herb for thousands of years. ${ }^{25}$ It has a beneficial effect on the digestive and respiratory systems. ${ }^{26}$ The leaves and flowering stems are strongly antiseptic, antispasmodic, carminative, cholagogue, diaphoretic, emmenagogue, expectorant, stimulant, stomachic, and mildly tonic. ${ }^{27}$ The principal objective of the present study was focused on the chemical composition and antibacterial potential of essential oils of $S$. macrosiphon, $R$. officinalis, D. polychaetum, and O. vulgare against 4 bacteria causing food poisoning in human (i.e., Staphylococcus aureus, Bacillus cereus, Salmonella enterica, and Listeria monocytogenes).

\section{Materials and Methods}

Plant Materials and Essential Oil Extraction

Aerial parts of 4 medicinal plants from Labiatae family including S. macrosiphon, R. officinalis, D. polychaetum, and $O$. vulgare were collected from Hezar Mountain located in Rayen, Kerman province, Iran. Essential oils were extracted from $200 \mathrm{~g}$ of air-dried aerial parts of the plants by hydrodistillation method using Clevenger-type apparatus for 3 hours. The obtained oil was dried over anhydrous sodium sulfate and put in sealed vials at $4^{\circ} \mathrm{C} .^{28}$

Bacterial Strains and Antibacterial Assay

Cultures of S. aureus PTCC 1431 (Persian Type Culture Collection), B. cereus PTCC 1015, S. enterica PTCC 1709, and L. monocytogenes ATCC 7644 (American Type Culture Collection) were used for antibacterial assessment of the essential oils. All strains were routinely grown aerobically in Trypticase soy broth (TSB) medium (Merck, Germany) with shaking for 24 hours at $37^{\circ} \mathrm{C}$. Antibacterial activity was assessed in the presence of different concentrations of the essential oils by serial dilution method using dimethyl sulfoxide/methanol $(1: 1 \mathrm{v} / \mathrm{v})$ solvent. ${ }^{29}$ In the present study, the antibacterial activity was evaluated using agar disc diffusion method. ${ }^{30}$ The bacterial suspension of $1.5 \times 10^{8}$ cells $/ \mathrm{mL}$ in sterile normal saline (adjusted to $0.5 \mathrm{McF}$ arland standard) was prepared and inoculated on Muller-Hinton agar medium (Merck, Germany) by sterile cotton swab. ${ }^{31}$ Essential oils were assayed in triplicate. Each microbial inoculum was spread evenly on to the surface of MullerHinton agar (Merck, Germany) plates with a sterile swab. Then, the sterilized blank discs were placed in the center of every inoculated agar plate. $20 \mu \mathrm{L}$ of essential oil with $80 \mathrm{mg} /$ $\mathrm{mL}$ concentration was infused in the filter paper discs $(6 \mathrm{~mm}$ size)..$^{32}$ Dimethyl sulfoxide/methanol $(1: 1 \mathrm{v} / \mathrm{v})$ was used as the negative control, while broad-spectrum antibiotics such as Amikacin was used as the positive control for obtaining comparable results. All plates were incubated for 24 hours at $37^{\circ} \mathrm{C}$. Following the incubation, antibacterial activity was determined by measuring the inhibition zone around the discs in $\mathrm{mm}$.

\section{Determination of Minimum Inhibitory Concentration}

In order to determine the minimum inhibitory concentration (MIC), two-fold dilution series (80, 40, 20, 10, 5, 2.5, and 1.25 $\mathrm{mg} / \mathrm{mL}$ ) of each essential oil were prepared and bioassayed in broth dilution method. ${ }^{33,34}$ The least concentration at which no visible growth was obtained in agar plates was considered as MIC.

\section{Identification of the Oil Components}

The oil composition was analyzed by GC and GC/MS. The GC analysis of the volatile components was carried out using a Hewlett-Packard 6890 instrument coupled to a flame ionization detector (FID). Compounds were separated on an HP-5 capillary column $(30 \mathrm{~m} \times 0.25 \mathrm{~mm}$, film thickness $0.25 \mu \mathrm{m}$. The oven temperature was programmed as follows: $60^{\circ} \mathrm{C}$ to $220^{\circ} \mathrm{C}$ at $3^{\circ} / \mathrm{min}$, injector temperature of $250^{\circ} \mathrm{C}$; detector temperature of $270^{\circ} \mathrm{C}$; and helium $(1 \mathrm{~mL} / \mathrm{min})$ as the carrier gas. A mixture of aliphatic hydrocarbons $\left(\mathrm{C}_{6}-\right.$ $\mathrm{C}_{23}$ ) in hexane was directly injected into the GC injector under the above temperature program in order to calculate the retention indices of each compound. Retention indices were determined using the retention times of n-alkanes $\left(\mathrm{C}_{6}-\mathrm{C}_{23}\right)$ that were injected after the essential oil under the same chromatographic conditions. The retention indices for all components were determined according to the method using $\mathrm{n}$-alkanes as standard. GC/MS analysis was performed using an Agilent 5975C mass spectrometer coupled to an Agilent 7890A gas chromatograph equipped with an HP$5 \mathrm{MS}$ capillary column $(30 \mathrm{~m} \times 0.25 \mathrm{~mm}$, film thickness 0.25 $\mu \mathrm{m})$. The carrier gas was helium, and the chromatographic conditions were as above. The spectrometer was scanned over the 40-400 amu range with an ionization voltage of $70 \mathrm{eV}$ and an ionization current of $150 \mu \mathrm{A}$. The compounds were identified by comparison of retention indices (RI, HP-5) with those reported in the literature and by comparing their mass spectra with the Adams and Wiley libraries as well as those stored in NIST library. ${ }^{35}$

\section{Results}

The essential oil composition of the 4 evaluated medicinal plants from the Labiatae family, including S. macrosiphon, $R$. officinalis, D. polychaetum, and O. vulgare, was analyzed by GC-MS. From the GC-MS analysis, 11 compounds 
representing 93.9\% of the total essential oil composition of Salvia macrosiphon was identified (Table 1, Figure 1). Linalool (54.8\%) and manool (27.3\%) were introduced as the principal components of $S$. macrosiphon essential oil. Fourteen compounds representing $91.0 \%$ of the total essential oil composition of $R$. officinalis were identified based on GC-MS analysis (Figure 2, Table 2). a-Pinene (15.5\%), verbenone (14.3\%), 1, 8- cineole (12.4\%), camphor (11.9\%), bornyl acetate (7.9\%), borneol (6.5\%), and camphene (5.8\%) were the major components. Through the GC-MS analysis, five compounds representing $92.8 \%$ of the total essential oil composition of D. polychaetum was identified (Figure 3, Table 3 ). The main components of the essential oil were MethylCyclo geranate (69.9\%) and Limonene (19.9\%). Major components constituted up to $90 \%$ of the D. polychaetum essential oil, whereas other components were present only as a trace. Finally, twenty components were identified in the essential oil of $O$. vulgare based on the GC-MS analysis (Figure 4, Table 4). Thymol (27.4\%), $\gamma$-terpinene (12.1\%), terpinene-4-OL (11.6\%), trans-sabinene hydrate $(5.9 \%)$,

Table 1. Chemical Composition of Salvia macrosiphon Essential Oil

\begin{tabular}{llcc}
\hline Peak No. & Compound & RI & Peak Area \% \\
\hline 1 & Hexanol & 871 & 1.4 \\
\hline 2 & 1 ,8-Cineole & 1031 & 1.1 \\
\hline 3 & Fenchone & 1087 & 1.1 \\
\hline 4 & Linalool & 1097 & 54.8 \\
\hline 5 & Terpinene-4-OL & 1177 & 1.0 \\
\hline 6 & $\alpha$-Terpineole & 1189 & 1.7 \\
\hline 7 & Methyl chavicol & 1196 & 1.1 \\
\hline 8 & Spathulenol & 1578 & 1.7 \\
\hline 9 & $\alpha$ - Murolol & 1646 & 1.4 \\
10 & Manoyl oxide & 1998 & 1.3 \\
\hline 11 & Manool & 2057 & 27.3 \\
\hline
\end{tabular}

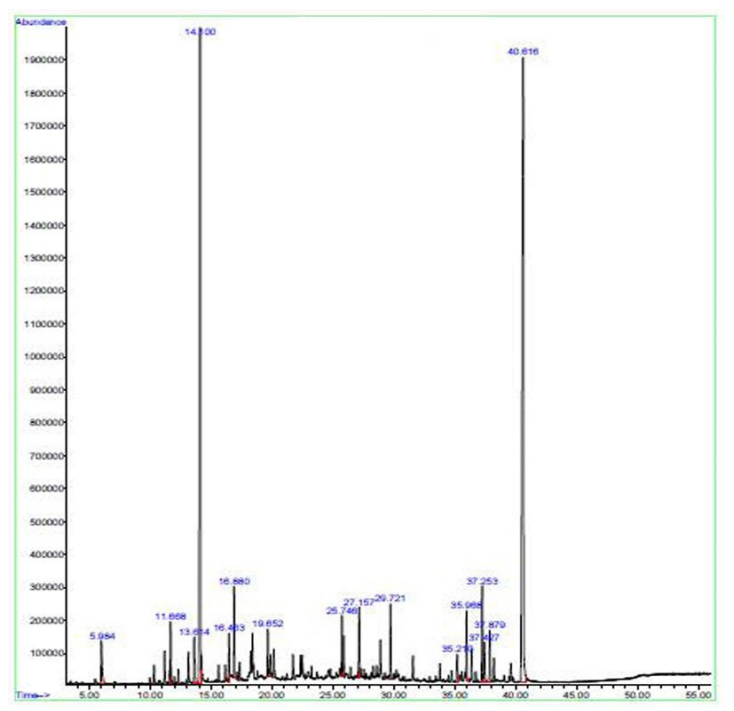

Figure 1. GC-MS Analysis of the Essential Oils From Salvia macrosiphon. and trans-anethole (3.6\%) were the major constituents of $O$. vulgare essential oil.

As mentioned before, the antimicrobial activity of the oils was evaluated using the dilution method. Based on the obtained results, all of the bacteria were sensitive to the $S$. macrosiphon essential oil in the lowest concentration. The essential oil from $R$. officinalis exhibited antibacterial activity against the three non-spore forming tested bacterial strains. The spore-forming bacteria, $B$. cereus, was resistant to all concentration of the rosemary oil. The oil of $D$. polychaetum inhibited all the tested gram-positive and gram-negative bacteria from growing. The most sensitive bacteria to this oil was B. cereus (PTCC 1015). Based on the obtained results, the Gram-positive bacteria were more susceptible to the $D$. polychaetum essential oil compared to the gram-negative bacterium, S. enterica. The essential oil of O. vulgare also showed antibacterial activity against all tested bacterial strains. L. monocytogenes (ATCC 7644) was the most susceptible bacteria in comparison with the other three species. The MIC and $\mathrm{MBC}$ of the essential oils for all tested bacterial species are summarized in Table 5.

\section{Discussion}

The antimicrobial effects of medicinal plant essential oils and extracts justify them to be used in many fields such as medicine, food industry, and pharmacy. Medicinal plants have constantly been used as sources for finding new drugs. ${ }^{36}$ Numerous investigations have been conducted about the application of essential oils as antimicrobial agents and shown to increase the safety and shelf life of food products beside being used as a flavoring agent in foods. ${ }^{3,37}$ The first investigation on the antibacterial properties of plant essential oils has been carried out by Dla Croix in $1881 .^{3}$ Regarding the understanding of the biological potentials inherent in the essential oils of plants, their chemical constituents are determined to elucidate the effectiveness of their bioactive compositions. Essences or essential oils are aromatic oily liquids extracted from various aromatic plants' materials

Table 2. Chemical Composition of Rosmarinus officinalis Essential Oil

\begin{tabular}{llcc}
\hline Peak No. & Compound & RI & Peak Area \% \\
\hline 1 & $\alpha$-Pinnene & 939 & 15.5 \\
\hline 2 & Camphene & 954 & 5.8 \\
\hline 3 & 3-Octane & 984 & 3.9 \\
\hline 4 & $\beta$-Myrcene & 991 & 2.3 \\
\hline 5 & Ortho-Cymene & 1026 & 1.6 \\
\hline 6 & $1,8-$ Cineole & 1031 & 12.4 \\
\hline 7 & Linalool & 1097 & 4.1 \\
\hline 8 & Camphor & 1146 & 11.9 \\
\hline 9 & Borneol & 1169 & 6.5 \\
\hline 10 & Terpinene-4-OL & 1177 & 1.5 \\
11 & $\alpha$-Terpineole & 1189 & 1.7 \\
\hline 12 & Verbenone & 1205 & 14.3 \\
\hline 13 & Bornyl Acetate & 1289 & 7.9 \\
\hline 14 & Trans-Caryophyllene & 9141 & 1.6 \\
\hline & Total percentage & - & 91.0 \\
\hline
\end{tabular}




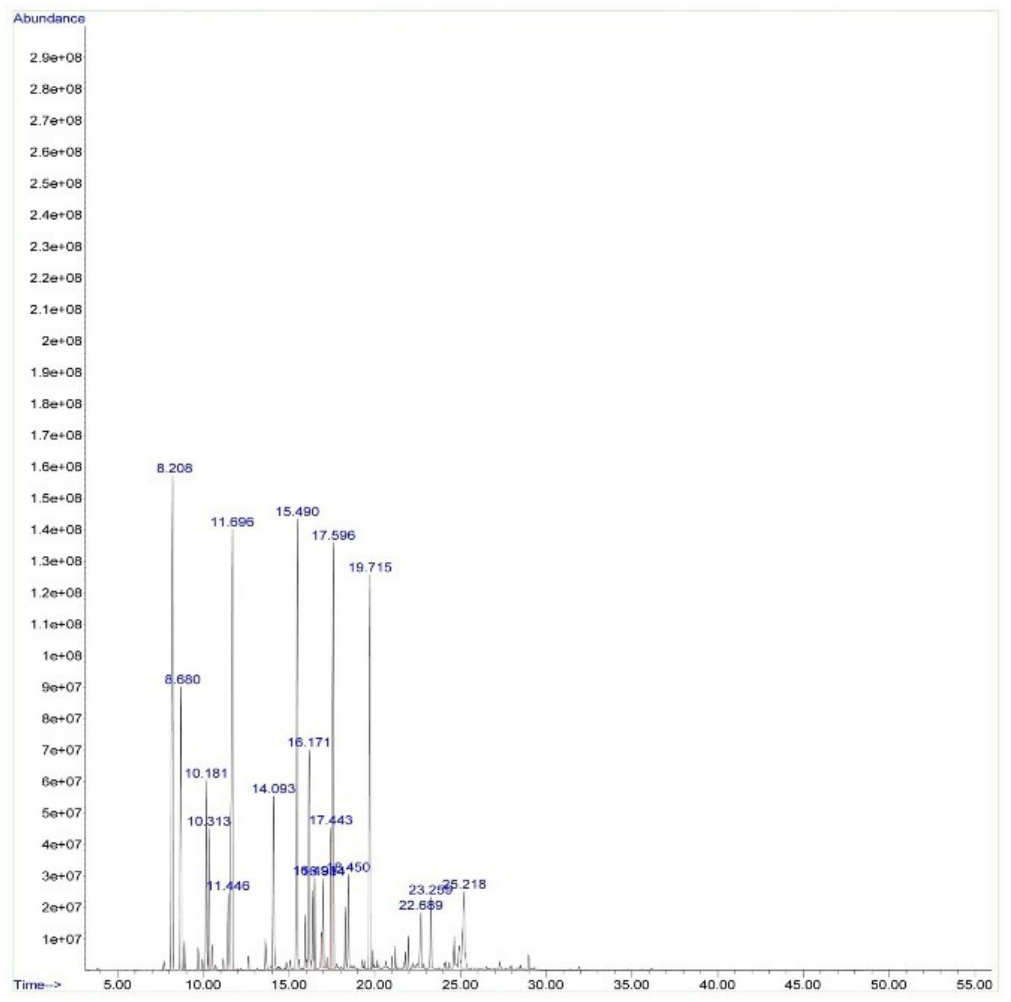

Figure 2. GC-MS Analysis Of Essential Oils From Rosmarinus officinalis.

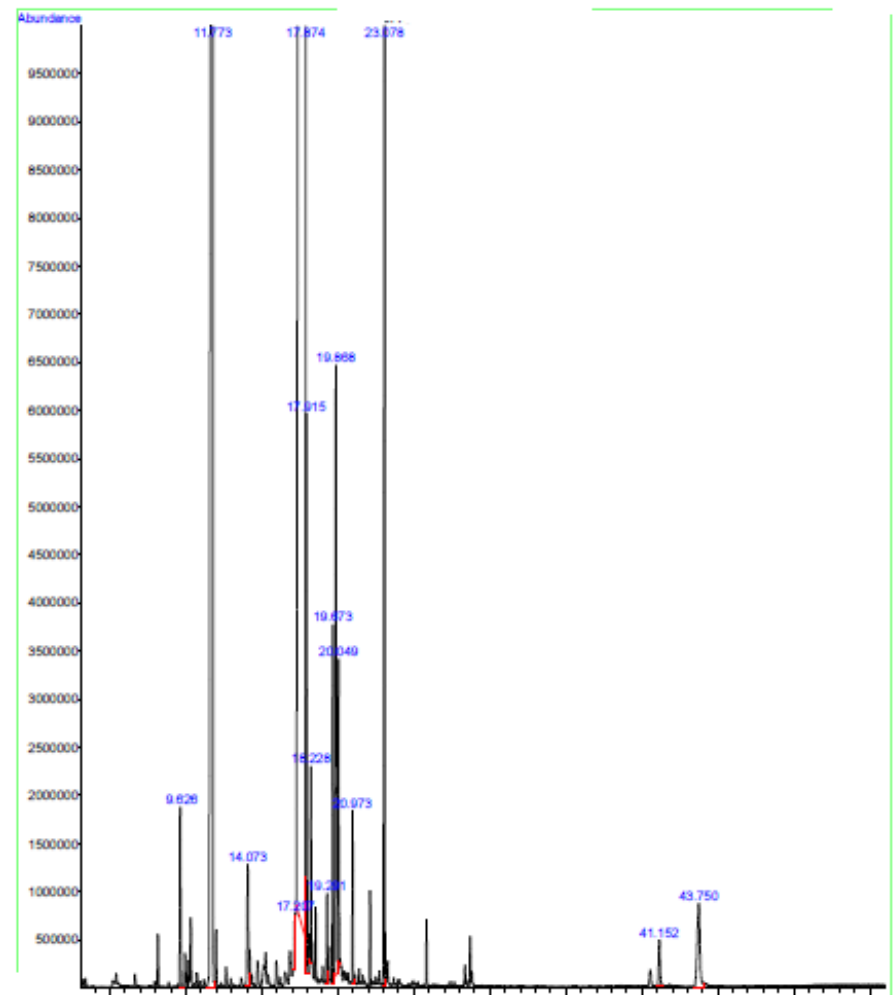

Figure 3. GC-MS Analysis of Essential Oils From Dracocephalum polychaetum.

such as flowers, buds, seeds, leaves, twigs, bark, herbs, wood, fruits, and roots. ${ }^{37}$ The most interesting area for application of essential oil is the growth inhibition and reduction in numbers of more dangerous foodborne pathogens such as
Salmonella spp., Escherichia coli O157:H7, L. monocytogenes, S. aureus, and B. cereus in foods. ${ }^{38}$ Based on our results, one of the investigated herbs, S. macrosiphon, was rich in a wide variety of secondary metabolites. In addition, the minimum 
Table 3. Chemical Composition of Dracocephalum polychaetum Essential Oil

\begin{tabular}{llcc}
\hline Peak No. & Compound & RI & Peak Area \% \\
\hline 1 & Sabinene & 975 & 0.5 \\
\hline 2 & Limonene & 1029 & 19.9 \\
3 & Linalool & 1097 & 0.5 \\
\hline 4 & Methyl-Cyclogeranate & 1198 & 69.9 \\
5 & p-Menth-1-En-9-OL & 1295 & 2.0 \\
& Total percentage & - & 92.8 \\
\hline
\end{tabular}

Table 4. Chemical Composition of Origanum vulgare Essential Oil

\begin{tabular}{|c|c|c|c|}
\hline Peak No. & Compound & $\mathbf{R I}$ & Peak Area \% \\
\hline 1 & Thymol & 1290 & 27.4 \\
\hline 2 & $\gamma$-Terpinene & 1060 & 12.1 \\
\hline 3 & Terpinene-4-OL & 1177 & 11.6 \\
\hline 4 & $\alpha$-Terpinene & 1017 & 6.4 \\
\hline 5 & trans-Sabinene hydrate & 1098 & 5.9 \\
\hline 6 & Carvacrol & 1299 & 5.3 \\
\hline 7 & p-Cymene & 1025 & 5.2 \\
\hline 8 & trans-Anethole & 1285 & 3.6 \\
\hline 9 & $\alpha$-Thujene & 930 & 2.8 \\
\hline 10 & Trans-Caryophyllene & 1419 & 2.5 \\
\hline 11 & $\alpha$-Terpinolene & 1089 & 2.4 \\
\hline 12 & cis-Sabinene hydrate & 1070 & 1.9 \\
\hline 13 & $\alpha$-Terpineole & 1189 & 1.8 \\
\hline 14 & Sabinene & 975 & 1.7 \\
\hline 15 & Borneol & 1169 & 1.2 \\
\hline 16 & $\beta$-Myrcene & 991 & 1.1 \\
\hline 17 & Carvacrol Methyl Ether & 1245 & 1.0 \\
\hline 18 & $\alpha$-Eudesmole & 1654 & 0.8 \\
\hline 19 & $\beta$-Eudesmole & 1651 & 0.7 \\
\hline \multirow[t]{2}{*}{20} & $\alpha$-Pinnene & 939 & 0.7 \\
\hline & Total percentage & - & 96.1 \\
\hline
\end{tabular}

inhibitory and bactericidal concentration results showed that its essential oil represented a significant antibacterial activity against both gram-positive and gram-negative bacteria. In agreement with this, the antimicrobial activity of many species of Salvia plants against several microorganisms has been documented for decades and has been attributed to the presence of 1,8-cineole, $\beta$-thujone, camphor, borneol, and p-cymene. ${ }^{39}$ Also, in another investigation, the composition of the essential oil of $S$. macrosiphon has been investigated by GLC and GC-MS. The main constituents of the oil were reported as linalool (26.3\%), hexyl hexanoate (9.6\%), hexyl isovalerate $(9.3 \%)$, hexyl-2-methyl-butanoate (8.9\%), sclareol (7.2\%), and hexyl octanoate (6.1\%). ${ }^{40}$ In a similar study, the chemical constituents of the essential oil from S. macrosiphon were identified, and the major components of the $S$. macrosiphon oil contained $\alpha$-gurjunene (11\%), $\beta$-cubebene $(10.6 \%)$, and germacrene-B (7\%). ${ }^{41}$ Also, identification of some flavonoids has been reported from the aerial parts of $S$. macrosiphon grown in Lorestan province, Iran. ${ }^{41}$ In another study, 24 volatile compounds were identified in S. macrosiphon essential oil. The major components were reported to be

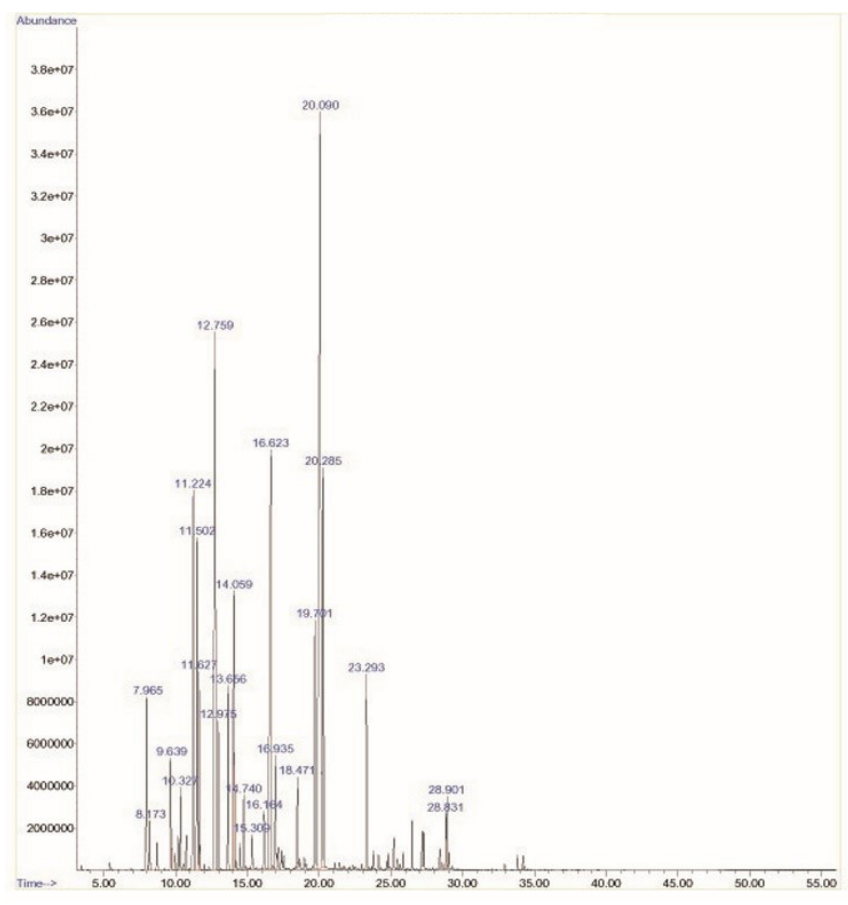

Figure 4. GC-MS Analysis Of Essential Oils From Origanum vulgare.

Table 5. MIC and MBC (mg/mL) of 4 Essential Oils Against Bacterial Tested

\begin{tabular}{lcccc}
\hline \multirow{2}{*}{ Essential oil } & \multicolumn{4}{c}{ Bacteria } \\
\cline { 2 - 5 } S. macrosiphon & MIC: 2.5 & MIC* & MIC: 5 & MIC: 5 \\
& MBC: 5 & MBC* & MBC: 10 & MBC: 10 \\
\multirow{2}{*}{ R. officinalis } & MIC: 2.5 & MIC: 10 & MIC: 0.6 & MIC: 5 \\
& MBC: 5 & MBC: 10 & MBC: 0.6 & MBC: 10 \\
D. polychaetum & MIC: 5 & MIC: 0.6 & MIC: 10 & MIC: 5 \\
& MBC: 10 & MBC: 0.3 & MBC: 20 & MBC: 10 \\
O. vulgare & MIC: 0.15 & MIC: 0.3 & MIC: 0.3 & MIC: 0.6 \\
& MBC: 0.3 & MBC: 0.3 & MBC: 0.6 & MBC: 1.25 \\
\hline
\end{tabular}

* No antibacterial activity against $B$. cereus.

linalool, hexyl isovalerate, hexyl 2-methyl butyrate, and $\delta$-cadinen. ${ }^{42}$ Our study showed that $S$. macrosiphon essential oil was effective against 4 human bacterial pathogens. This could provide a potential source of new antibacterial agents, which is valuable for clinical trials and the food industry. It was also shown that the effective antibacterial activity of the oil could be related to its main constituents, i.e., linalool (54.8\%) and manool (27.3\%).

In the present work, the major compounds of $R$. officinalis essential oils were $\alpha$-pinene (15.5\%), verbenone (14.3\%), 1 , 8 -cineole (12.4\%), and camphor (11.9\%); and the oil had the best activity on the 3 non-spore forming bacteria. $R$. officinalis essential oils from other geographical locations have been extensively studied as well. In a study conducted by the Balkan Peninsula, the main compounds of $R$. officinalis essential oil were 1,8-cineole, camphor, $a$-pinene, and borneol. ${ }^{43}$ In another investigation, the most important constituents of the Iranian rosemary were shown to be 1,8-cineole, $a$-pinene, berbonone, and camphor. ${ }^{44}$ Similar investigation showed that 1,8 -cineole and $\alpha$-pinene were major constituents of the rosemary oil. ${ }^{45}$ 
Antimicrobial activity of the positive enantiomers of pinene has been shown against Candida albicans, Cryptococcus neoformans, Rhizopus oryzae, and methicillin-resistant Staphylococcus aureus (MRSA). ${ }^{46}$ In similar studies, the antimicrobial activity of 1,8 -cineole has been identified. ${ }^{47,48}$ In another study, the essential oil of Feverfew plant (Tanacetum parthenium) was rich in camphor and was considered as an anti-bacterial agent in drug and food industries. ${ }^{49}$ Another experimented herb in this investigation, D. polychaetum, was rich in a wide variety of secondary metabolites such as Methyl-Cyclo geranate (69.9\%) and limonene (19.9\%).

In addition, the MIC results showed that the essential oil of D. polychaetum presented a significant antibacterial activity against gram-positive bacteria. The antibacterial activity of the oil can be attributed to its main constituents. MethylCyclo geranate is used in fragrances and cosmetics including in shampoos, soaps, and body deodorants; and Limonene is employed as a flavoring agent in perfumes, creams, soaps, and in some food products. In addition, limonene has been found to possess antifungal and antimicrobial effects. ${ }^{50}$ In the present study, S. enterica was considered less susceptible than grampositive bacteria to the $D$. polychaetum oil. It is suggested that gram-negative bacteria possess cell membrane restricting the diffusion of hydrophobic compounds through their outer membrane envelope. ${ }^{3}$ About the other studied essential oil, extracted from $O$. vulgare, all tested bacteria were susceptible to the oil and L. monocytogenes (ATCC 7644) was the most susceptible bacteria. In addition, thymol (27.4\%), terpinene4-ol (11.6\%), $\gamma$-terpinene (12.1\%), a-terpinene (6.4\%), transsabinene hydrate $(5.9 \%)$, and p-cymene $(5.2 \%)$ were the main components of the oil. Thymol exerts antimicrobial activity because of its phenolic structure. ${ }^{51}$ It is also used as a preservative, and as an active antiseptic ingredient in some kinds of toothpaste which are used to reduce plaque and gingivitis. ${ }^{52}$ In another study, the antibacterial activity of the essential oil of $O$. vulgare L. on multi-resistant bacteria isolated from biological materials was assessed. Their results showed that 4 samples of E. coli, Enterococcus faecalis, and MRSA, three samples of Acinetobacter baumannii, and a sample of Klebsiella pneumoniae were inhibited by the essential oil at the concentration $0.125 \%, 0.125 \%$, and $0.5 \%$, respectively. ${ }^{27}$ In a similar research, the antimicrobial activity of oregano essential oil in a food system was evaluated, and results showed that the addition of oregano essential oil to sausage could be a promising route as its bacteriostatic effect. In the same report, analysis of the oil identified that terpinen-4-ol and $\gamma$-terpinene were the major components. ${ }^{5}$ Pirigharnaei et al showed that the oregano essential oil is composed of carvacrol, thymol, and linalool as major components, followed by $\gamma$-terpinene, p-cymene, linalool, terpinen-4-ol, and sabinene hydrate as the second main components of $O$. vulgare. $^{53,54}$ The difference between the types and percentages of chemical compositions of the essential oils can depend on the season of harvesting, geographical situation, ground conditions, genetic factors, part of the plant, etc, and hence, to the phenological stage of the plant as well as the method of essential oil extraction. ${ }^{55}$ The level of the antibacterial activities of the essential oil could also be attributed to the hydrophobicity of the constituents allowing the oil to disturb the lipids of the bacterial cell membrane, making them more permeable and causing leakages of cellular components and ions. $^{56,57}$ Also, some oil constituents are able to infiltrate the cells; then, involve in some cellular metabolic mechanisms, interfere with active sites of some enzymes, and intervene some other cellular metabolisms. ${ }^{58}$ Totally, the extracted oils of these 4 plants showed relatively high MIC against $B$. cereus, S. aureus, L. monocytogenes, and S. enterica.

\section{Conclusions}

The present study suggests the studied essential oils as a potential source for antibacterial compounds confirming them as sources of antibacterial agent required for therapeutic and food preservative applications.

\section{Authors' Contributions}

$\mathrm{AK}, \mathrm{MM}$ and $\mathrm{MMF}$ were involved in study design and data collections. $A K, M M, M M F, H T$ and $M M M$ were involved in writing, preparing and revising of this research article.

\section{Conflict of Interest Disclosures}

The authors declare they have no conflicts of interest.

\section{Acknowledgments}

This work was supported by the Microbiology and Chemistry Department, Kerman Branch, Islamic Azad University, Kerman, Iran. The authors are grateful to Dr. Peyman Rajaei for collection and identification of the plants.

\section{References}

1. Moravej H, Moravej Z, Yazdanparast M, et al. Antimicrobial peptides: features, action, and their resistance mechanisms in bacteria. Microb Drug Resist. 2018;24(6):747-767. doi:10.1089/ mdr.2017.0392.

2. Guarrera PM. Traditional phytotherapy in Central Italy (Marche, Abruzzo, and Latium). Fitoterapia. 2005;76(1):1-25. doi:10.1016/j. fitote.2004.09.006.

3. Burt S. Essential oils: their antibacterial properties and potential applications in foods--a review. Int J Food Microbiol. 2004;94(3):223-253. doi:10.1016/j.ijfoodmicro.2004.03.022.

4. Chovanová R, Mikulášová $M$, Vaverková $S$. In vitro antibacterial and antibiotic resistance modifying effect of bioactive plant extracts on methicillin-resistant Staphylococcus epidermidis. Int J Microbiol. 2013;2013:760969. doi:10.1155/2013/760969.

5. Busatta C, Mossi AJ, Rodrigues MRA, Cansian RL, de Oliveira JV. Evaluation of Origanum vulgare essential oil as antimicrobial agent in sausage. Braz J Microbiol. 2007;38(4):610-616. doi:10.1590/ s1517-83822007000400006.

6. Venturi CR, Danielli LJ, Klein F, et al. Chemical analysis and in vitro antiviral and antifungal activities of essential oils from Glechon spathulata and Glechon marifolia. Pharm Biol. 2015;53(5):682688. doi:10.3109/13880209.2014.936944.

7. Oliva Mde L, Carezzano ME, Gallucci MN, Demo MS. Antimycotic effect of the essential oil of Aloysia triphylla against Candida species obtained from human pathologies. Nat Prod Commun. 2011;6(7):1039-1043.

8. Sharma P, Shah GC. Composition and antioxidant activity of Senecio nudicaulis Wall. ex DC. (Asteraceae): a medicinal plant growing wild in Himachal Pradesh, India. Nat Prod Res. 2015;29(9):883-886. doi:10.1080/14786419.2014.990904.

9. Esperandim VR, da Silva Ferreira D, Sousa Rezende KC, et al. In vitro antiparasitic activity and chemical composition of the essential oil obtained from the fruits of Piper cubeba. Planta Med. 2013;79(17):1653-1655. doi:10.1055/s-0033-1351022. 
10. Du SS, Yang K, Wang CF, et al. Chemical constituents and activities of the essential oil from Myristica fragrans against cigarette beetle Lasioderma serricorne. Chem Biodivers. 2014;11(9):1449-1456. doi:10.1002/cbdv.201400137.

11. Raja RR. Medicinally potential plants of Labiatae (Lamiaceae) family: an overview. Res J Med Plants. 2012;6(3):203-213. doi:10.3923/rjmp.2012.203.213.

12. Delnavazi M-R, Baba-Ali F, Soufiabadi S, et al. Essential oil composition, antioxidant activity and total phenolic content of some Lamiaceae taxa growing in Northwest of Iran. Pharm Sci. 2014;20(1):22-28.

13. Sarac N, Ugur A. Antimicrobial activities and usage in folkloric medicine of some Lamiaceae species growing in Mugla, Turkey. Eurasia J Biosci. 2007;4:28-37.

14. Gohari AR, Ebrahimi H, Saeidnia S, Foruzani M, Ebrahimi P, Ajani Y. Flavones and flavone glycosides from Salvia macrosiphon Boiss. Iran J Pharm Res. 2011;10(2):247-251.

15. Kahraman A, Celep F, Doğan M. A New Record for the Flora of Turkey: Salvia macrosiphon Boiss. (Labiatae). Turk J Bot. 2009;33(1):53-55.

16. Bai N, He K, Roller M, et al. Flavonoids and phenolic compounds from Rosmarinus officinalis. J Agric Food Chem. 2010;58(9):53635367. doi:10.1021/jf100332w.

17. Park JB. Identification and quantification of a major anti-oxidant and anti-inflammatory phenolic compound found in basil, lemon thyme, mint, oregano, rosemary, sage, and thyme. Int J Food Sci Nutr. 2011;62(6):577-584. doi:10.3109/09637486.2011.562882.

18. Begum A, Sandhya S, Shaffath Ali S, Vinod KR, Reddy S, Banji D. An in-depth review on the medicinal flora Rosmarinus officinalis (Lamiaceae). Acta Sci Pol Technol Aliment. 2013;12(1):61-73.

19. Huang MT, Ho CT, Wang ZY, et al. Inhibition of skin tumorigenesis by rosemary and its constituents carnosol and ursolic acid. Cancer Res. 1994;54(3):701-708.

20. Sonboli A, Gholipour A, Mirjalili MH, Amini Rad M. Molecular characterization of Iranian Dracocephalum (Lamiaceae) species based on RAPD data. Acta Biol Szeged. 2011;55(2):227-230.

21. Lazarević $P$, Lazarević $M$, Krivošej $Z$, Stevanović V. On the distribution of Dracocephalum ruyschiana (Lamiaceae) in the Balkan Peninsula. Phytol Balc. 2009;15(2):175-179.

22. Mehrabani M, Roholahi S, Foruomadi A. Phytochemical studies of Dracocephalum polychaetum Bornm. Journal of Medicinal Plants. 2005;4(16):36-42. [Persian].

23. Amirghofran Z, Azadbakht M, Karimi MH. Evaluation of the immunomodulatory effects of five herbal plants. J Ethnopharmacol. 2000;72(1-2):167-172. doi:10.1016/s0378-8741(00)00234-8.

24. Kokkini S, Vokou D, Karousou R. Morphological and chemical variation of Origanum vulgare L. Bot Chronika. 1991;10:337-346.

25. Deans SG, Svoboda KP. The antimicrobial properties of marjoram (Origanum majorana L.) volatile oil. Flavour Fragr J. 1990;5(3):187190. doi:10.1002/ffj.2730050311.

26. McCue P, Vattem D, Shetty K. Inhibitory effect of clonal oregano extracts against porcine pancreatic amylase in vitro. Asia Pac J Clin Nutr. 2004;13(4):401-408.

27. da Costa AC, dos Santos BHC, Santos Filho L, de Oliveira Lima E. Antibacterial activity of the essential oil of Origanum vulgare L. (Lamiaceae) against bacterial multiresistant strains isolated from nosocomial patients. Rev Bras Farmacogn. 2009;19(1):236-241. doi:10.1590/s0102-695x2009000200010.

28. Sepahvand R, Delfan B, Ghanbarzadeh S, Rashidipour M, Veiskarami GH, Ghasemian-Yadegari J. Chemical composition, antioxidant activity and antibacterial effect of essential oil of the aerial parts of Salvia sclareoides. Asian Pac J Trop Med. 2014;7S1:S491-496. doi:10.1016/s1995-7645(14)60280-7.

29. Moosazadeh E, Akhgar MR, Kariminik A. Chemical composition and antimicrobial activity of Opuntia stricta F. essential oil. Journal of Biodiversity and Environmental Sciences. 2014;4(5):94-101.

30. Klančnik A, Piskernik S, Jeršek B, Možina SS. Evaluation of diffusion and dilution methods to determine the antibacterial activity of plant extracts. J Microbiol Methods. 2010;81(2):121126. doi:10.1016/j.mimet.2010.02.004.

31. Nalubega R, Kabasa JD, Olila D, Kateregga J. Evaluation of antibacterial activity of selected ethnomedicinal plants for poultry in Masaka district, Uganda. Research Journal of Pharmacology. 2011;5(2):18-21. doi:10.3923/rjpharm.2011.18.21.

32. Shakiba M, Kariminik A, Parsia P. Antimicrobial activity of different parts of Phoenix dactylifera. International Journal of Molecular and Clinical Microbiology. 2011;1(2):107-111.

33. Yu J, Lei J, Yu H, Cai X, Zou G. Chemical composition and antimicrobial activity of the essential oil of Scutellaria barbata. Phytochemistry. 2004;65(7):881-884. doi:10.1016/j. phytochem.2004.02.005.

34. National Committee for Clinical Laboratory Standards (NCCLS). Reference method for broth dilution antifungal susceptibility testing of yeasts. Approved Standard M27-A2. 2nd ed. Wayne, PA: NCCLS; 2002.

35. Adams RP. Identification of essential oil components by gas chromatography/mass spectrometry. Allured Publishing Corporation; 2007.

36. Al-Mariri A, Safi M. The antibacterial activity of selected labiatae (Lamiaceae) essential oils against Brucella melitensis. Iran J Med Sci. 2013;38(1):44-50.

37. Bajpai VK, Baek KH, Kang SC. Control of Salmonella in foods by using essential oils: a review. Food Res Int. 2012;45(2):722-734. doi:10.1016/j.foodres.2011.04.052.

38. Mann CM, Markham JL. A new method for determining the minimum inhibitory concentration of essential oils. J Appl Microbiol. 1998;84(4):538-544. doi:10.1046/j.13652672.1998.00379.x.

39. Dyer LA, Palmer AD. Piper: A Model Genus for Studies of Phytochemistry, Ecology, and Evolution. New York: Springer; 2004.

40. Javidnia K, Miri R, Jamalian A. Composition of the essential oil of Salvia macrosiphon Boiss. from Iran. Flavour Fragr J. 2005;20(5):542-543. doi:10.1002/ffj.1468.

41. Matloubi Moghddam F, Moridi Farimani M, Taheri S, Tafazoli M, Amin G. Chemical constituents from Salvia macrosiphon. Chem Nat Compd. 2008;44(4):518-519. doi:10.1007/s10600-0089111-2.

42. Rowshan V, Karimi S. Essential oil composition and allelopathic affect of Salvia macrosiphon Boiss. on Zea mays L. International Journal of Agriculture. 2013;3(4):788-794.

43. Lakušić DV, Ristić MS, Slavkovska VN, Sinžar-Sekulić JB, Lakušić BS. Environment-related variations of the composition of the essential oils of rosemary (Rosmarinus officinalis L.) in the Balkan Penninsula. Chem Biodivers. 2012;9(7):1286-1302. doi:10.1002/ cbdv.201100427.

44. Jalali-Heravi M, Moazeni RS, Sereshti H. Analysis of Iranian rosemary essential oil: application of gas chromatography-mass spectrometry combined with chemometrics. J Chromatogr A. 2011;1218(18):2569-2576. doi:10.1016/j.chroma.2011.02.048.

45. Jiang Y, Wu N, FuYJ, et al. Chemical composition and antimicrobial activity of the essential oil of Rosemary. Environ Toxicol Pharmacol. 2011;32(1):63-68.doi:10.1016/j.etap.2011.03.011.

46. Rivas da Silva AC, Lopes PM, Barros de Azevedo MM, Costa DC, Alviano CS, Alviano DS. Biological activities of alpha-pinene and beta-pinene enantiomers. Molecules. 2012;17(6):6305-6316. doi:10.3390/molecules17066305.

47. van Vuuren SF, Viljoen AM. Antimicrobial activity of limonene enantiomers and 1,8-cineole alone and in combination. Flavour Fragr J. 2007;22(6):540-544. doi:10.1002/ffj.1843.

48. Hendry ER, Worthington T, Conway BR, Lambert PA. Antimicrobial efficacy of eucalyptus oil and 1,8-cineole alone and in combination with chlorhexidine digluconate against microorganisms grown in planktonic and biofilm cultures. J Antimicrob Chemother. 2009;64(6):1219-1225. doi:10.1093/jac/dkp362.

49. Saharkhiz MJ, Satari M, Goudarzi GR, Omid Beygi R. Assessment of antibacterial properties of Tanacetum parthenium L. essential oil. 
Iranian Journal of Medicinal and Aromatic Plants. 2008;24(1):4755. [Persian].

50. Espina L, Gelaw TK, de Lamo-Castellví S, Pagán R, García-Gonzalo D. Mechanism of bacterial inactivation by (+)-limonene and its potential use in food preservation combined processes. PLoS One. 2013;8(2):e56769. doi:10.1371/journal.pone.0056769.

51. Masada Y. Analysis of Essential Oils By Gas Chromatography and Mass Spectrometry. New York: Wiley; 1976.

52. Dorman HJ, Deans SG. Antimicrobial agents from plants: antibacterial activity of plant volatile oils. J Appl Microbiol. 2000;88(2):308-316. doi:10.1046/j.1365-2672.2000.00969.x.

53. García MA1, Sanz J. Analysis of Origanum vulgare volatiles by direct thermal desorption coupled to gas chromatography-mass spectrometry. J Chromatogr A. 2001;918(1):189-194. doi:10.1016/ s0021-9673(01)00750-6.

54. Pirigharnaei M, Zare S, Heidary R, Khara J, EmamaliSabzi R, Kheiry F. The essential oils compositions of Iranian Oregano (Origanum vulgare L.) populations in field and provenance from Piranshahr district, West Azarbaijan province, Iran. Avicenna J Phytomed.
2011;1(2):106-114. doi:10.22038/ajp.2011.129.

55. Teixeira B, Marques A, Ramos C, et al. Chemical composition and antibacterial and antioxidant properties of commercial essential oils. Ind Crops Prod. 2013;43:587-595. doi:10.1016/j. indcrop.2012.07.069.

56. Raybaudi-Massilia RM, Mosqueda-Melgar J, Soliva-Fortuny R, Martín-Belloso O. Control of pathogenic and spoilage microorganisms in fresh-cut fruits and fruit juices by traditional and alternative natural antimicrobials. Compr Rev Food Sci Food Saf. 2009;8(3):157-180. doi:10.1111/j.1541-4337.2009.00076.x.

57. Oussalah M, Caillet S, Saucier L, Lacroix M. Inhibitory effects of selected plant essential oils on the growth of four pathogenic bacteria: E. coli O157:H7, Salmonella Typhimurium, Staphylococcus aureus and Listeria monocytogenes. Food Control. 2007;18(5):414-420. doi:10.1016/j.foodcont.2005.11.009.

58. Wang CY, Wang SY, Chen C. Increasing antioxidant activity and reducing decay of blueberries by essential oils. J Agric Food Chem. 2008;56(10):3587-3592. doi:10.1021/jf7037696. 